\title{
Effects of fuel treatments on California mixed-conifer forests
}

by Eric M. Winford, Jens T. Stevens and Hugh D. Safford

Land managers implement forest fuel reduction treatments, including prescribed fire, mastication, and hand-and mechanical thinning, to modify wildfire behavior. Fuel treatments decrease tree density, increase mean canopy base height and remove surface fuels, and have been shown to reduce fire severity in yellow pine and mixed-conifer forests, even under relatively severe weather conditions. However, less is known about the impacts of fuel treatments on other facets of forest ecology. Synthesizing evidence from the scientific literature regarding their effects on forest structure, carbon, vegetation, soils, wildlife and forest pests, we found a developing consensus that fuel treatments, particularly those that include a prescribed fire component, may have neutral to positive effects on a number of ecological processes in frequent-fire coniferous forests and may increase forest resilience to future disturbance and stress.

$\mathrm{F}$ orest fuel treatments modify forest structure and composition to affect fire behavior and reduce fire severity in the event of fire. Properly implemented, they can also improve forest habitat for species of plants and animals, and restore ecological processes and

Online: http://californiaagriculture.ucanr.edu/

landingpage.cfm?article=ca.v069n03p150\&fulltext=yes doi: 10.3733/ca.v069n03p150 services (e.g., hydrologic function, soil nutrient cycling, subcanopy light availability, biodiversity, aesthetics) (McIver et al. 2012). Various fuel treatments have been developed, including prescribed fire, mechanical thinning, hand-thinning, mastication and combinations of these (Evans et al. 2011; Stephens et al. 2012).

Yellow pine and mixed-conifer (YPMC) forests cover millions of hectares of California forestland (Safford and Stevens, in press). These forests experience wet winters and dry summers and are generally composed of a variable mix of pine species (Pinus ponderosa, $P$. jeffreyi, P. lambertiana), white fir (Abies concolor), various oak species (Quercus spp.) and incense cedar (Calocedrus decurrens) (Barbour et al. 1993; Barbour et al. 2007). While there was substantial local variation, before Euro-American settlement in California this type of vegetation generally supported short fire return intervals (10 to 20 years), with a summer-fall fire season and fires dominated by low- and moderate-severity effects (Safford and Stevens, in press; Van de Water and Safford 2011; Van Wagtendonk and FitesKaufman 2006).

Until the early 20th century, those frequent low- to moderate-intensity fires with smaller patches of high-severity effects reduced the quantity and continuity of fuels in YPMC forests and created a complex patchwork of mixed-age tree clumps and gaps (Agee and Skinner 2005; North et al. 2009). Since then, however, fire exclusion practices, logging of large trees and livestock grazing have allowed fuel and young trees to accumulate in

A prescribed burn moves slowly through a forest in Sequoia National Park in June 2015. The burn is intended to help restore the area to more natural conditions by promoting sustainable tree growth and habitat for plants and animals while reducing tree density and ladder fuels. 
some stands for a century or more, leading to high loads of spatially continuous fuels (Barbour et al. 1993; Stephens and Ruth 2005) and increased risk of tree mortality from moisture stress and tree pests (Fettig et al. 2007; van Mantgem and Stephenson 2007). Increasing fuel loads, higher summer temperatures, prolonged late summer droughts and decreasing fuel moistures are combining to create circumstances in which wildfires that escape containment in YPMC forests can burn at much higher severity over larger areas in extreme weather conditions than was common under the presettlement fire regime (Mallek et al. 2013; Miller et al. 2009; Miller and Safford 2012; Steel et al. 2015).

In YPMC forests, fuel treatments have proven effective at reducing fire severity and tree mortality, restoring forest structure and protecting human infrastructure and lives across the western United States (Martinson and Omi 2013; Safford et al. 2009; Safford et al. 2012). They also hold promise as sources of forest biomass, which can be used to produce a variety of timber and nontimber forest products as well as energy through biomass burning (Evans and Finkral 2009). As a result, there is interest in greatly expanding the pace and scale of fuel treatments (North et al. 2012), making it important that both managers and the public understand the effects that fuel treatments have on forest ecology. Our goal was to synthesize current scientific literature on forest fuel treatments and their ecological effects in YPMC forests in the Sierra Nevada and southern Cascades and similar locations in the western United States.

\section{Fuel treatments, forest structure}

The primary objectives for fuel treatments are to create conditions in the forest in which fire can be more easily controlled, and where fire can occur without devastating ecological or socioeconomic consequences (Reinhardt et al. 2008). Forest fuel treatments target surface fuel (dead and down woody biomass, and dead and live shrubs and herbaceous material), which provides fuel for surface fires; ladder fuels (lower branches and

These 2011 photographs illustrate the effect of a fuels treatment implemented prior to the 2008 American River Complex fire in Placer County. Nearly all the trees in the treated stand, bottom, survived the fire, while many trees in the denser, untreated stand, top, did not. smaller trees), which allow a fire to move vertically into the canopy and contribute to torching; and canopy continuity (tree spacing), which creates conditions for active crown fire (Agee and Skinner 2005). Fuel treatments primarily remove dead fuels, shrubs and mostly small- and medium-sized live trees, although some larger trees may also be removed. This can be accomplished in a variety of ways (see Agee and Skinner 2005, Evans et al. 2011 and Schwilk et al. 2009 for overviews), but there are four major categories of treatment, which may be employed
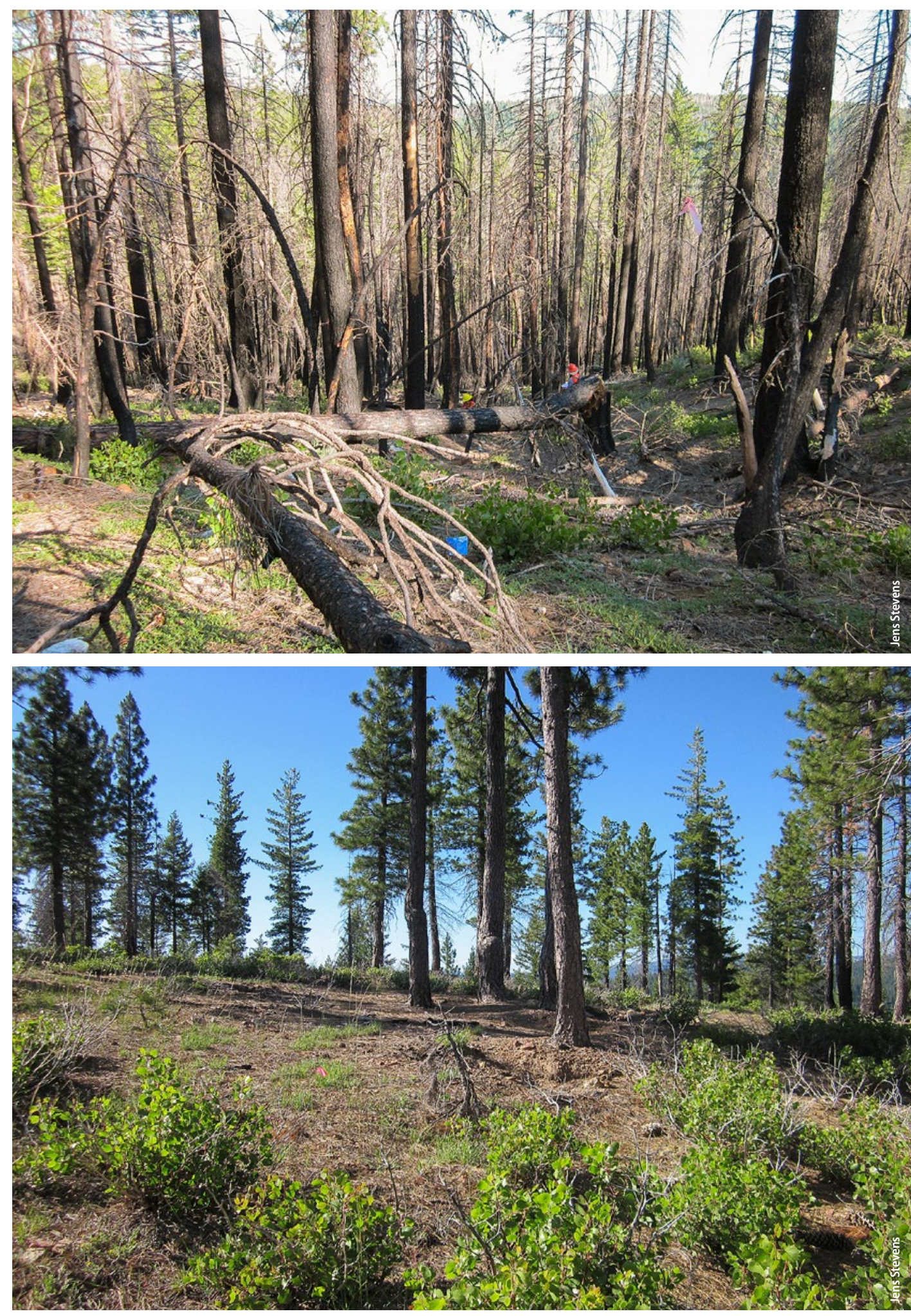
hand-thinning followed by prescribed fire or pile burning to dispose of surface fuel generated by the first treatment (Safford et al. 2012; Schwilk et al. 2009; Stephens et al. 2012).

\section{Effects on vegetation}

Fuel treatment effects on live forest vegetation can be distinguished as direct effects on target vegetation (trees and woody shrubs), indirect effects on nontarget vegetation, or indirect effects on vegetation by affecting subsequent wildfire severity. Most studies of treatment effects on vegetation compare differences between treatment regimes, and/or the effects of a specific regime versus vegetation in an untreated forest.

Direct effects. The primary direct effect of fuel treatments on target vegetation is a decrease in live tree basal area and density (Collins et al. 2007; Stevens et al. 2014; van Mantgem et al. 2011). During thinning operations, fire-intolerant species (e.g., fir) are often targeted and the composition of residual surviving trees can be shifted toward fire-tolerant species, like pines (Chiono et al. 2012); however, prescribed fire on its own does not necessarily shift tree species composition, because it rarely kills the large trees which contribute most of the seeds (van Mantgem et al. 2011). Abundance of tree seedlings generally decreases in the years immediately following treatments (Schwilk et al. 2009; Stevens et al. 2014) but recovers over time (Chiono et al. 2012).

Fuel treatments may also target shrubs for removal, but shrub responses to fuel treatments are complex. There is evidence that mechanical thinning, prescribed fire, or a combination of the two can reduce shrub cover (Collins et al. 2007; Wayman and North 2007) or have no effect (Chiono et al. 2012; Collins et al. 2007; Stevens et al. 2014) over a span of 1 to 5 years posttreatment. Shrubs may respond positively to treatments over longer time periods by resprouting and regenerating from seed (Kane et al. 2010; Stevens et al. 2014), particularly when prescribed fire is used, as fire scarifies the seeds of many common montane chaparral species (Stephens et al. 2012). One way to reduce shrub recruitment is to repeatedly burn the site at time intervals short enough to exhaust the energy reserves of resprouting shrubs and to inhibit recovery of the shrub seedbank (Busse et al. 2009).
Indirect effects. The most commonly studied responses of nontarget vegetation to fuel treatments are herbaceous productivity and understory species diversity. Herbaceous productivity (generally measured by plant cover) often shows little or no response to fuel treatments in the Sierra Nevada and southern Cascades, over either the short term ( 1 to 2 years, Collins et al. 2007) or long term (2 to 15 years, Busse et al. 2009). However, at a national level, treatments often do increase herbaceous productivity (Stephens et al. 2012), suggesting that at more mesic sites, where the understory vegetation is less limited by moisture stress, treatments may stimulate increased plant cover and richness (Stevens et al. 2015). Mastication alone does not necessarily reduce understory species cover or richness, but when masticated material is tilled into the soil or, especially, prescribe-burned, there can be significant increases in bare ground and reductions in litter, which lead to much higher understory cover (with a major component of fire-scarified shrubs) and diversity (Kane et al. 2010).

Responses of native plant diversity to treatments appear to depend on the treatment regime and time since treatment. Collins et al. (2007) found a slight decrease in native diversity following mechanical thinning, but no change following prescribed fire only, during the first 2 years post-treatment. Studies measuring native plant diversity from 2 to 20 years following treatments involving the use of prescribed fire generally show a moderate to strong increase in diversity relative to controls (Kane et al. 2010; Stevens et al. 2015; Wayman and North 2007; Webster and Halpern 2010).

In YPMC forests, non-native species richness and cover tend to increase following treatments, particularly when they involve mastication or mechanical thinning followed by prescribed fire (Collins et al. 2007; Kane et al. 2010; Stevens et al. 2014). This is consistent with findings from other regions (Freeman et al. 2007; Schwilk et al. 2009; Stephens et al. 2012). However, non-native species richness in untreated forests that burn at high severity has been shown to exceed non-native species richness in treated forests, both in California (Stevens et al. 2015) and nationally (Freeman et al. 2007). These findings indicate that low- and moderate-severity fires may reduce the risk of non-native plant invasion compared with high-severity fires in some cases.

Finally, treatments can indirectly affect all vegetation through their moderation of subsequent wildfire severity. When untreated forest burns under severe fire weather conditions, fire severity is generally high (Martinson and Omi 2013; Safford et al. 2012; Stevens et al. 2014). When treated forest burns in a wildfire, there is generally less effect on the forest overstory than in untreated forest, suggesting that treatments can increase forest resilience to future disturbance. This overstory resilience translates to understory resilience: compared with untreated stands, treated stands after wildfire have more tree regeneration, less shrub regeneration and higher native species diversity at the stand scale (Stevens et al. 2014; Stevens et al. 2015). Native species diversity at the plot scale increases following both low- and high-severity fires, but diversity at the stand scale is greater following low-severity fires (Stevens et al. 2015), possibly because some species that are not adapted to fire may be able to persist during low fire intensity, and even among fire-adapted species, some may prefer low-intensity fire to high-intensity fire (Rocca 2009). Thus, stand-scale diversity can likely be maintained at high levels under a heterogeneous regime of predominantly low- and moderate-severity fires with smaller patches of high severity.

\section{Effects on carbon}

While fuel treatments reduce the carbon stocks of forests by removing biomass, they also benefit the long-term ecosystem carbon equation by reducing the carbon emissions from subsequent wildfires. There is great interest in increasing the carbon in forests to reduce the impacts of global warming but there is also much uncertainty and debate about the total extent of the carbon benefits of fuels treatments (Campbell et al. 2012; McKinley et al. 2011). Because of their high fire risk and moderate productivity, YPMC forests may not be optimal places to try to sustainably sequester large amounts of carbon, but properly implemented fuel treatments can at least theoretically reduce fire severity sufficiently to maintain ecosystem carbon over the long term (Hurteau et al. 2008; Mitchell et al. 2009), provided the reduced fuel structure is maintained over time by future 
to include canopy gaps or patches of highseverity fire, either through mechanical treatments, prescribed fire or managed wildfire (Fontaine and Kennedy 2012 ).

A handful of studies have looked at impacts of fuels treatment on species of conservation concern, such as the California spotted owl (Strix occidentalis), the fisher (Martes pennanti) and the marten (Martes americana), though the studies are limited in the number of individuals, other wildlife species were unaffected. They argue that increased heterogeneity in treatments may improve the persistence of spotted owls in actively managed forest (Stephens et al. 2014).

\section{Effects on pests and pathogens}

Reducing stand density can lead to notable reductions in bark beetle attacks, mostly by increasing tree vigor (Fettig et al. 2007). However, managers should be

\section{High native species diversity can be maintained by recurring low- and moderate-severity fires following initial fuel treatments.}

locations and scales they encompassed. At a stand scale, fuel treatments that avoid removing large live trees, large dead standing trees and large dead downed trees will best preserve important nesting, roosting and foraging habitat for multiple species (Keane 2014; Zielinski 2014).

The preferred late-seral habitat for fisher and spotted owl may experience short-term reductions in quality from the removal of woody biomass, including snags and downed woody debris, but the long-term benefit to the species is reducing the risk of stand-replacing fire, which could reduce nesting habitat quality for these species for a longer period of time (Lee and Irwin 2005; Scheller et al. 2011). Reductions in canopy cover from lateseason prescribed fires and mechanical thinning plus fire can reduce the quality of fisher roosting habitat, but foraging habitat remains unaffected (Truex and Zielinski 2013).

Roberts et al.'s (2011) finding that spotted owls can persist in a landscape that has a low- to mixed-severity fire regime also suggests that fuel treatment effects may be relatively minor and transitory. Stephens et al. (2014) found that fuel treatments with an even tree spacing focused on fire hazard reduction caused a decline in spotted owl nesting activity, while most

\section{References}

Agee JK, Skinner CN. 2005. Basic principles of forest fuel reduction treatments. Forest Ecol Manag 211:83-96.

Barbour MG, Keeler-WolfT, Schoenherr AA. 2007. Terrestrial vegetation of California. (3rd edition). Berkeley and Los Angeles, CA: University of California Press. 730 p. Barbour MG, Pavlik BM, Lindstrom S. 1993. California's Changing Landscapes: Diversity and Conservation of California Vegetation. Sacramento: California Native Plant Society. 244 p. aware that fuel treatments may also cause indirect mortality from pests. Relatively low levels of delayed mortality ( $5 \%$ to $10 \%$ ) can occur from beetles following treatment, particularly in treatments that include prescribed fire (Maloney et al. 2008; Stark et al. 2013). Where prescribed fire is used, post-treatment beetle-caused mortality can increase with fire severity (Breece et al. 2008; McHugh et al. 2003; Parker et al. 2006). Insect pests may also be attracted to thin-only activities that leave fuels on the ground (Fettig et al. 2007), although mastication may help prevent this (Stark et al. 2013).

Studies vary in whether Abies or Pinus species show more susceptibility to bark beetle attack following prescribed fire, though most agree that sugar pine shows higher incidence of indirect mortality than would be expected by chance alone (Maloney et al. 2008; Stark et al. 2013). Thinning treatments may reduce mistletoe abundance on larger trees, though thinning may also exacerbate the spread of root diseases such as Armillaria and Heterobasidion annosum (Maloney et al. 2008).

\section{Conclusion}

Ten years ago, we had a limited scientific understanding about the effectiveness of forest fuel treatments in YPMC forests and the effects they may have on forest ecology. Today, we know that certain treatments - for example, mechanical and/or hand-thinning followed by some sort of prescribed fire, or prescribed fire alone - are very effective at reducing wildfire severity. We are also learning that the ecological impacts of such fuel treatment combinations are not necessarily negative, indeed they are more often neutral to positive. This speaks to the restorative ability of forest thinning and prescribed fire in formerly fire-prone forests that have experienced a century of fire exclusion and a century and a half of other human impacts, including the removal of most large firetolerant trees and their replacement by high densities of smaller, less fire-tolerant species. Most scientific studies of the ecological impacts of fuel treatments in YPMC forests have been short term and small scale. There is a great need to scale upward and outward in our investigations of forest management impacts on YPMC forests, especially with respect to their landscape-level impacts on forest resilience to ecosystem stressors such as climate change, fire, prolonged drought, insects and disease. CA

\footnotetext{
E.M. Winford was Sierra Nevada Coordinator for the California Fire Science Consortium and currently is Teanaway Community Forest Planner in the Washington Department of Natural Resources; J.T. Stevens is Postdoctoral Researcher in the John Muir Institute for the Environment at UC Davis; and H.D. Safford is USDA Forest Service Regional Ecologist for the Pacific Southwest Region and Affiliated Research Ecologist at UC Davis.

We would like to thank our editor and anonymous reviewers for their constructive comments on the original draft. We also acknowledge helpful input from Bev Bulaon, Danny Cluck and Malcolm North.
}

Boerner REJ, Huang J, Hart SC. 2009. Impacts of fire and fire surrogate treatments on forest soil properties: a meta-analytical approach. Ecol Appl 19:338-58.

Breece CR, Kolb TE, Dickson BG, et al. 2008. Prescribed fire effects on bark beetle activity and tree mortality in southwestern ponderosa pine forests. Forest Ecol Manag 255:119-28.
Busse MD, Cochran PH, Hopkins WE, et al. 2009. Developing resilient ponderosa pine forests with mechanical thinning and prescribed fire in central Oregon's pumice region. Can J Forest Res 39:1171-85.

Busse MD, Shestak CJ, Hubbert KR, Knapp EE. 2010. Soil physical properties regulate lethal heating during burning of woody residues. Soil Sci Soc Am J 74:947-55. 
Caldwell TG, Johnson DW, Miller WW, Qualls RG. 2002. Forest floor carbon and nitrogen losses due to prescription fire. Soil Sci Soc Am J 66:262-67.

Campbell, JL, Harmon ME, Mitchell SR. 2012. Can fuel reduction treatments really increase forest carbon sequestration by reducing future fire emissions? Front Eco Environ 10:83-90.

Carlson CH, Dobrowski SZ, Safford HD. 2012. Variation in tree mortality and regeneration affect forest carbon recovery following fuel treatments and wildfire in the Lake Tahoe Basin, California, USA. Carbon Balance Manag 7:7. doi:10.1186/1750-0680-7-7

Chiono LA, O'Hara KL, De Lasaux MJ, et al. 2012. Development of vegetation and surface fuels following fire hazard reduction treatment. Forests 3:700-22.

Collins BM, Moghaddas JJ, Stephens SL. 2007. Initial changes in forest structure and understory plant communities following fuel reduction activities in a Sierra Nevada mixed conifer forest. Forest Ecol Manag 239:102-11. Evans AM, Everett RG, Stephens SL, Youtz JA. 2011. Comprehensive Fuels Treatment Practices Guide for Mixed Conifer Forests: California, Central and Southern Rockies, and the Southwest. Joint Fire Science Program fuel treatment guide. Santa Fe, NM: The Forest Guild. 112 p.

Evans AM, Finkral AJ. 2009. From renewable energy to fire risk reduction: a synthesis of biomass harvesting and utilization case studies in US forests. Glob Change Biol Bioenergy 1:211-19.

Fettig CJ, Klepzig KD, Billings RF, et al. 2007. The effectiveness of vegetation management practices for prevention and control of bark beetle infestations in coniferous forests of the western and southern United States. Forest Ecol Manag 238:24-53.

Fontaine JB, Kennedy PL. 2012. Meta-analysis of avian and small-mammal response to fire severity and fire surrogate treatments in U.S. fire-prone forests. Ecol Appl 22:1547-61.

Freeman JP, Stohlgren TJ, Hunter ME, et al. 2007. Rapid assessment of postfire plant invasions in coniferous forests of the western United States. Ecol Appl 17:1656-65.

Hurteau M, North M. 2010. Carbon recovery rates following different wildfire risk mitigation treatments. Forest Ecol Manag 260: 930-7.

Hurteau MD, Koch GW, Hungate BA. 2008. Carbon protection and fire risk reduction: toward a full accounting of forest carbon offsets. Front Ecol Environ 6:493-98.

Hutto RL. 2008. The ecological importance of severe wildfires: some like it hot. Ecol Appl 18:1827-34.

Johnson DW, Fenn ME, Miller WW, Hunsaker CF. 2009. Fire effects on carbon and nitrogen cycling in forests of the Sierra Nevada. Dev Environ Sci 8:405-23.

Kane JM, Varner JM, Knapp EE, Powers RF. 2010. Understory vegetation response to mechanical mastication and other fuels treatments in a ponderosa pine forest. Appl Veg Sci 13:207-20.

Keane JJ. 2014. California spotted owl: scientific considerations for forest planning. In: Long JW, Quinn-Davidson L, Skinner CN (eds.). Science Synthesis to Support Socioecological Resilience in the Sierra Nevada and Southern Cascade Range. Gen. Tech. Rep. PSW-GTR-247. Albany, CA USDA Forest Service, Pacific Southwest Research Station Lee DC, Irwin LL. 2005. Assessing risks to spotted owls from forest thinning in fire-adapted forests of the western United States. Forest Ecol Manag 211:191-209.

Mallek C, Safford H, Viers J, Miller J. 2013. Modern departures in fire severity and area vary by forest type, Sierra Nevada and southern Cascades, California, USA. ECOsphere 4:art153. http://dx.doi.org/10.1890/ES13-00217.1. Maloney PE, Smith TF, Jensen CE, et al. 2008. Initial tree mortality and insect and pathogen response to fire and thinning restoration treatments in an old-growth mixedconifer forest of the Sierra Nevada, California. Can J Forest Res 38:3011-20.
Martinson EJ, Omi PN. 2013. Fuel Treatments and Fire Severity: A Meta-Analysis. Res. Pap. RMRS-RP-103WWW. Fort Collins, CO: USDA Forest Service, Rocky Mountain Research Station. $38 \mathrm{p}$.

McHugh CW, Kolb TE, Wilson JL. 2003. Bark beetle attacks on ponderosa pine following fire in northern Arizona. Environ Entomol 32:510-22.

Mclver JD, Stephens SL, Agee JK, et al. 2012. Ecological ef fects of alternative fuel-reduction treatments: highlights of the National Fire and Fire Surrogate study (FFS). Int J Wildland Fire 21:894-904.

McKinley DC, Ryan MG, Birdsey RA, et al. 2011. A synthesis of current knowledge on forests and carbon storage in the United States. Ecol Appl 21:1902-24.

Miller JD, Safford H. 2012. Trend in wildfire severity: 1984 to 2010 in the Sierra Nevada, Modoc Plateau, and southern Cascades, California, USA. Fire Ecol 8:41-57.

Miller JD, Safford HD, Crimmins M, Thode AE. 2009. Quantitative evidence for increasing forest fire severity in the Sierra Nevada and southern Cascade Mountains, California and Nevada, USA. Ecosystems 12:16-32.

Minocha R, Turlapati SA, Long S, North N. 2013. Fuel treatment effects on soil chemistry and foliar physiology of three coniferous species at the Teakettle Experimental Forest, California, USA. Trees 27:1101-13.

Mitchell SR, Harmon ME, O'Connell KE. 2009. Forest fuel reduction alters fire severity and long-term carbon storage in three Pacific Northwest ecosystems. Ecol Appl 19:643-55.

Moghaddas EEY, Stephens SL. 2007. Thinning, burning, and thin-bum fuel treatment effects on soil properties in a Sierra Nevada mixed-conifer forest. Forest Ecol Manag 250:156-66.

Murphy JD, Johnson DW, Miller WW, et al. 2006. Prescribed fire effects on forest floor and soil nutrients in a Sierra Nevada forest. Soil Science 171:181-99.

North M, Collins BM, Stephens S. 2012. Using fire to increase the scale, benefits, and future maintenance of fuels treatments. J Forest 110:392-401.

North MP, Hurteau MD. 2011. High-severity wildfire effects on carbon stocks and emissions in fuels treated and untreated forest. Forest Ecol Manag 261:1115-20.

North M, Stine P, O'Hara K, et al. 2009. An ecosystem management strategy for Sierran mixed-conifer forests. USDA Forest Service, PSW General Technical Report. PSW-GTR-220

Parker TJ, Clancy KM, Mathiasen RL. 2006. Interactions among fire, insects and pathogens in coniferous forests of the interior western United States and Canada. Agr Forest Entomol 8:167-89.

Reinhardt ED, Keane RE, Calkin DE, Cohen JD. 2008. Objectives and considerations for wildland fuel treatment in forested ecosystems of the interior western United States. Forest Ecol Manag 256:1997-2006.

Roberts SL, Van Wagtendonk JW, Miles AK, Kelt DA. 2011. Effects of fire on spotted owl occupancy in a late-successional forest. Biol Conserv 144:610-19.

Rocca ME. 2009. Fine-scale patchiness in fuel load can influence initial post-fire understory composition in a mixed conifer forest, Sequoia National Park, California. Nat Area J 29:126-32

Safford HD, Schmidt DA, Carlson CH. 2009. Effects of fuel treatments on fire severity in an area of wildland-urban interface, Angora Fire, Lake Tahoe Basin, California. Forest Ecol Manag 258:773-87.

Safford HD, Stevens JT, Merriam K, et al. 2012. Fuel treat ment effectiveness in California yellow pine and mixed conifer forests. Forest Ecol Manag 274:17-28.

Safford HD, Stevens JT. In press. Natural Range of Variation (NRV) for yellow pine and mixed conifer forests in the Sierra Nevada, southern Cascades, and Modoc and Inyo National Forests, California, USA. Albany, CA: USDA Forest Service, Pacific Southwest Research Station.
Scheller RM, Spencer WD, Rustigian-Romsos H, et al. 2011. Using stochastic simulation to evaluate competing risks of wildfires and fuels management on an isolated forest carnivore. Landscape Ecol 26:1491-1504.

Schwilk DW, Keeley JE, Knapp EE. et al. 2009. The national Fire and Fire Surrogate study: effects of fuel reduction methods on forest vegetation structure and fuels. Ecol Appl 19:285-304.

Stark DT, Wood DL, Storer AJ, Stephens SL. 2013. Prescribed fire and mechanical thinning effects on bark beetle caused tree mortality in a mid-elevation Sierran mixed-conifer forest. Forest Ecol Manag 306:61-7.

Steel ZL, Safford HD, Viers JH. 2015. The fire frequencyseverity relationship and the legacy of fire suppression in California forests. Ecosphere 6:Article 8.

Stephens SL, Bigelow SW, Burnett RD, et al. 2014. California Spotted Owl, Songbird, and Small Mammal Responses to Landscape Fuel Treatments. BioScience 64:893-906

Stephens SL, Mclver JD, Boerner REJ, et al. 2012. The effects of forest fuel-reduction treatments in the United States. BioScience 62:549-60.

Stephens SL, Ruth LW. 2005. Federal forest-fire policy in the United States. Ecol Appl 15:532-42.

Stephenson NL, Das AJ, Condit R, et al. 2014. Rate of tree carbon accumulation increases continuously with tree size. Nature 507:90-3. doi:10.1038/nature12914

Stevens JT, Safford HD, Latimer AM. 2014. Wildfire-contingent effects of fuel treatments can promote ecological resilience in seasonally dry conifer forests. Can J Forest Res 44:843-54.

Stevens JT, Safford HD, Harrison S, Latimer AM. 2015 Forest disturbance accelerates thermophilization of understory plant communities. J Ecol. In press. doi:10.1111/1365-2745.12426

Truex RL, Zielinski WJ. 2013. Short-term effects of fuels treatments on fisher habitat in the Sierra Nevada, California. Forest Ecol Manag 293:85-91.

Van de Water KM, Safford HD. 2011. A summary of fire frequency estimates for California vegetation before Euro-American settlement. Fire Ecol 7:26-58.

van Mantgem PJ, Stephenson NL. 2007. Apparent climatically induced increase of tree mortality rates in a temperate forest. Ecol Lett 10:909-16.

van Mantgem PJ, Stephenson NL, Knapp E, et al. 2011 Long-term effects of prescribed fire on mixed conifer forest structure in the Sierra Nevada, California. Forest Ecol Manag 261:989-94.

Van Wagtendonk JW, Fites-Kaufman JA. 2006. Sierra Nevada bioregion. In: Sugihara, NG, Van Wagtendonk JW. Fites-Kaufman, J.A., et al. (eds.). Fire in California Ecosystems. Berkeley, CA: University of California Press.

Wayman RB, North M. 2007. Initial response of a mixedconifer understory plant community to burning and thinning restoration treatments. Forest Ecol Manag 239:32-44.

Webster KM, Halpern CB. 2010. Long-term vegetation responses to reintroduction and repeated use of fire in mixed-conifer forests of the Sierra Nevada. Ecosphere 1:1-27.

Winford EM, Gaither Jr JC. 2012. Carbon outcomes from fuels treatment and bioenergy production in a Sierra Nevada forest. Forest Ecol Manag 282:1-9.

Zielinski WJ. 2014. The forest carnivores: fisher and marten. In: Long JW, Quinn-Davidson L, Skinner CN (eds.). Science Synthesis to Support Socioecological Resilience in the Sierra Nevada and Southern Cascade Range. Gen. Tech. Rep. PSW-GTR-247. Albany, CA: USDA Forest Service, Pacific Southwest Research Station. 